\title{
Quantitative analysis of DNA strand break and oxidative stress enzymes in Saudi with non-insulin dependent diabetes mellitus patients
}

\begin{abstract}
Background: Non-insulin dependent diabetes mellitus (NIDDM) is a chronically progressive metabolic disorder, which strongly associated with high risk for cardiovascular disorders and mortality.

Objective: This study aims to quantitative analysis of DNA strand break and oxidative stress enzymes in Saudi NIDDM patients.

Materials and Methods: Twenty healthy subjects (group 1, mean age was 32.2 \pm 5.13 ), thirty patients with NIDDM had no diabetic complications (group 2, mean age was 40.1 \pm 5.78 ), and twenty patients with NIDDM had diabetic complications (group 3, mean age was $41.5 \pm 5.24$ ) participated in this study. Glucose profile, oxidative stress markers and DNA damage that may be induced by oxidative stress was measured in this study

Results: There were significant differences in the mean values of the oxidative stress markers (MDAP, MDAE, SOD and GSH) between the healthy subjects ( group 1) and patients with NIDDM had no diabetic complications (group 2), patients with NIDDM had diabetic complications (group 3).However, DNA single strand break was linear increase activity from group 1 to group 3. Moreover, there was significant correlation between the values of oxidative stress markers and the DNA single strand break $(\mathrm{P}<0.05)$.
\end{abstract}

Conclusion: There was an association between DNA strand break and poor antioxidant defense among patients with NIDDM patients.

Keywords: DNA quantitative analysis, oxidative stress, non-insulin dependent diabetes mellitus
Volume 6 Issue 3 - 2018

Mohammed H Saiem Al-Dahr

Department of Medical Laboratory Technology, Faculty of Applied Medical Sciences, King Abdulaziz University, Saudi Arabia

Correspondence: Mohammed H Saiem Al-Dahr, Department of Medical Laboratory Technology, Faculty of Applied Medical Sciences, King Abdulaziz University, P.O. Box 80324, Jeddah, 21589, Saudi Arabia, Email mdahr@kau.edu.sa

Received: April 17, 2018 | Published: May 30, 2018

\section{Introduction}

Over the previous 2 decades, non-insulin dependent diabetes (NIDDM) becomes a common health problem that lead to morbidity and mortality worldwide. ${ }^{1-3}$ However, both non-insulin dependent diabetes and obesity is progressively increased leads to high risk of dyslipidemia, coagulation disorders, insulin hormone resistance and cardiovascular complications. ${ }^{4,5}$ About $6 \%$ of populations are affected with diabetes worldwide. ${ }^{6,7}$

Diabetic complications are extensive and associated with multiple system dysfunction. ${ }^{8}$ Abnormal level of oxidative stress usually related to vascular diabetic complications. ${ }^{9}$ Obesity and diabetes are characterized with high levels of oxidative stress in comparison to the control group. ${ }^{10}$

Oxidative phosphorylation produces highly reactive molecules that induce tissue damage. ${ }^{11}$ DNA is the target site for the harmful effects of the oxidative markers, as oxidative markers induce breaks in the DNA strand. ${ }^{12}$ Shortened DNA telomeres has been reported in some NIDDM patients which was suggested to be related to abnormal levels of oxidative stress markers. ${ }^{13}$

The aim of this study was to measure the degree of the association between quantitative analysis of DNA strand break and oxidative stress markers among NIDDM patients.

\section{Materials and methods}

\section{Subjects}

Twenty healthy subjects (group 1, mean age was $32.2 \pm 5.13$ year), thirty patients with NIDDM had no diabetic complications (group 2, mean age was $40.1 \pm 5.78$ year), and twenty patients with NIDDM had diabetic complications (group 3, mean age was $41.5 \pm 5.24$ year) participated in this study.

\section{Laboratory analysis}

A. Measurement of oxidative stress markers and anti-oxidant status: Few millimeters of venous blood and plasma in EDTA vial were separated and were stored at $-80^{\circ} \mathrm{C}$ until analysis of markers of lipid peroxidation to include determining plasma levels of malondialdehyde-P (MDAP) and malondialdehyde-E (MDAE) were expressed as mmol/L. studied oxidative stress However, antioxidant status were studied by glutathione (GSH) and superoxide dismutase (SOD).

B. Measurement of glycosylated hemoglobin and serum glucose: Colorimetric method was used for estimation of glycosylated hemoglobin (HBA1c). However, Hitachi 912 Chemistry Analyzer using the hexokinase reagent from Boehringer Mannheim (Indianapolis, IN 46256) was used to measure serum glucose. 
C. Oxidative DNA damage measurement: The quantitative analysis of DNA strand break: was conducted in accordance with Tice et al. ${ }^{16}$ using the comet assay. However, the percentage of DNA in the comet tail and the tail moment are the comet parameters that was detected with Tritek Comet Score TM Free ware Version 1.5.

\section{Statistical analysis}

All variables were presented as mean \pm SD. However, Mann Whitney's U-test measured comparison between the mean values of the three groups. Moreover, Pearson's correlation coefficient (r) was used to detect the degree of correlation between the oxidative stress markers and the DNA single strand break.

\section{Results}

Serum glucose and HbAlc (\%) levels of the three groups were presented in Table 1, there were significant differences between the healthy subjects (group 1) and patients with NIDDM had no diabetic complications (group 2), patients with NIDDM had diabetic complications (group 3).
Table I Serum Glucose and HbAlc level in control healthy group, patients with controlled T2DM and patients with uncontrolled T2DM

\begin{tabular}{llll}
\hline & Group (1) & Group (2) & Group (3) \\
\hline Glucose $(\mathrm{mg} / \mathrm{dl})$ & $84 \pm 7$ & $151 \pm 10^{*}$ & $207 \pm 14^{*}$ \\
HbAIC (\%) & $5 \pm 0.53$ & $6.7 \pm 0.85^{*}$ & $8.03 \pm 0.4 I^{*}$ \\
\hline
\end{tabular}

$* \mathrm{p}<0.001$ as compared with control.

Concerning the results of oxidative stress markers (MDAP, MDAE, SOD and GSH), there were significant differences between the healthy subjects (group 1) and patients with NIDDM had no diabetic complications (group 2), patients with NIDDM had diabetic complications (group 3).However, DNA single strand break was linear increase activity from group 1 to group 3 as shown in Table 2. Moreover, there was significant degree of correlation between the values of oxidative stress markers and the DNA single strand break as shown in Table 3.

Table 2 The oxidative stress, anti-oxidant enzyme and DNA single strand break in the three groups

\begin{tabular}{lllll}
\hline & Group I & Group 2 & Group 3 & P value \\
\hline MDAP $(\mathrm{nmol} / \mathrm{ml})$ & $0.33 \pm 0.04$ & $0.42 \pm 0.1^{*}$ & $0.47 \pm 0.05^{*}$ & 0.001 \\
MDAE $(\mathrm{nmol} / \mathrm{ml})$ & $0.71 \pm 0.12$ & $0.81 \pm 0.15^{*}$ & $0.88 \pm 0.18^{*}$ & 0.014 \\
SOD $(\mathrm{U} / \mathrm{mg}$ protein) & $4.62 \pm 1.66$ & $4.25 \pm 1.44^{*}$ & $3.05 \pm 1.12^{*}$ & 0.009 \\
GSH $(\mathrm{mU} / \mathrm{mg}$ protein) & $75.15 \pm 14.27$ & $64.3 \pm 13.65^{*}$ & $57.8 \pm 15.23^{*}$ & 0.001 \\
Strand Break (Tail moment) & $2.5 \pm 0.73$ & $5.4 \pm 1.03^{*}$ & $8.7 \pm 1.55^{*}$ & 0.001 \\
\hline
\end{tabular}

$* \mathrm{p}<0.005$ as compared with control.

Table 3 Correlation coefficient ( $r$ ) of DNA single strand break and oxidative stress markers in the three groups

\begin{tabular}{llll}
\hline & $\begin{array}{l}\text { Group I } \\
\text { Strand Break (Tail moment) }\end{array}$ & $\begin{array}{l}\text { Group 2 } \\
\text { Strand Break (Tail moment) }\end{array}$ & $\begin{array}{l}\text { Group 3 } \\
\text { Strand Break (Tail moment) }\end{array}$ \\
MDAP $(\mathrm{nmol} / \mathrm{ml})$ & $0.6310^{*}$ & $0.582 I^{*}$ & $0.5765^{*}$ \\
$\mathrm{MDAE}(\mathrm{nmol} / \mathrm{ml})$ & $0.8112 * *$ & $0.6136 *$ & $0.5519 *$ \\
$\mathrm{SOD}(\mathrm{U} / \mathrm{mg}$ protein) & $-0.6321 *$ & $-0.7143^{* *}$ & $-0.6225^{*}$ \\
$\mathrm{GSH}(\mathrm{mU} / \mathrm{mg}$ protein) & $-0.7643 * *$ & $-0.6924 * *$ & $-0.7139 * *$ \\
\hline
\end{tabular}

Spearman's correlation was used **: $\mathrm{P}<0.01 *: \mathrm{P}<0.05$

There are several serious complications associated with NIDDM as cardiovascular complications which are related to increased oxidative stress, inflammatory cytokines and insulin resistance that are linked with DNA strand break. ${ }^{17,18}$ Moreover, abnormal levels oxidative stress induce many diabetic complications ${ }^{19-21}$ as antioxidant defense is poor that is induced by the metabolic disturbances among patients with NIDDM.22

Concerning oxidative stress markers, the mean values of MDAP and MDAE were significantly higher and the mean values of SOD and GSH were significantly lower among NIDDM patients in comparison to normal control subjects. Our results agreed with Kumawat and colleagues $^{23}$ reported that GSH significantly reduced and MDA significantly elevated in diabetic patients. Similarly, Kavitha and colleagues stated that diabetic patients had elevated MDA levels. ${ }^{24}$
Moreover; many studies found an elevation in the MDA levels in patients with NIDDM compared with non-diabetics. ${ }^{25-27}$ Similarly, several studies found significant higher level of MDA and fasting plasma glucose among poorly controlled NIDDM. ${ }^{28-30}$ In the other hand, reduced GSH levels were reported among patients with NIDDM. $^{31-35}$ Similarly, Moussa proved an association between hyperglycemia and GSH depletion. ${ }^{36}$

Regarding DNA single strand break, there was linear increase activity from group 1 to group 3 in DNA single strand break. Moreover, there was significant correlation between the values of oxidative stress markers and the DNA single strand break. Previous studies reported that prolonged exposure to hyperglycemia induces abnormal levels of oxidative stress markers in NIDDM patients that causes DNA damage. ${ }^{37-40}$ 


\section{Conclusion}

There was an association between DNA strand break and poor antioxidant defense among patients with NIDDM patients.

\section{Acknowledgments}

None.

\section{Conflict of interest}

The author declares there is no conflict of interest.

\section{References}

1. Wild S, Roglic G, Green A, et al. Global prevalence of diabetes: estimates for the year 2000 and projections for 2030. Diabetes Care. 2004;27(5):1047-1053.

2. Shaw JE, Sicree RA, Zimmet PZ. Global estimates of the prevalence of diabetes for 2010 and 2030. Diabetes Res Clin Pract. 2010;87(1):4-14.

3. Danaei G, Finucane MM, Lu Y, et al. National, regional, and global trends in fasting plasma glucose and diabetes prevalence since 1980 systematic analysis of health examination surveys and epidemiological studies with 370 country-years and 2.7 million participants. Lancet. 2011;378(9785):31-40

4. Rao Kondapally Seshasai S, Kaptoge S, Thompson A, et al. Diabetes mellitus, fasting glucose, and risk of cause-specific death. $N$ Engl J Med. 2011;364:829-841.

5. Dall T, Zhang Y, Chen Y, et al. The economic burden of diabetes. Health Aff (Millwood). 2010;29(2):297-303.

6. IDF Diabetes Atlas. 2011

7. The united states of diabetes: challenges and opportunities in the decade ahead. Working paper 5. UnitedHealth Group; 2010.

8. Cade WT. Diabetes-relatedmicrovascular andmacrovascular diseases in the physical therapy setting. Phys Ther. 2008;88(11):1322-35.

9. Chaudhuri A, Umpierrez GE. Oxidative stress and inflammation in hyperglycemic crises and resolution with insulin: implications for the acute and chronic complications of hyperglycemia. J Diabetes Complications. 2012;26(4):257-258.

10. Saad EA. Curative and protective effects of L-arginine on carbon tetrachloride- induced hepatotoxicity in mice. Biochem Biophys Res Commun. 2012;423(1):147-51.

11. Piperi C, Adamopoulos C, Dalagiorgou G, et al. Crosstalk between advanced glycation and endoplasmic reti-culum stress: emerging therapeutic targeting for metabolic diseases. J Clin Endocrinol Metab. 2012;97(7):2231-2242

12. Bruna Santos da Silva, Diego Luiz Rovaris, Rafaela Milan Bonotto, et al. The influence on DNA damage of glycaemic parameters: oralantidiabetic drugs and polymorphisms of genes involved in the DNA repairsystem. Mutagenesis. 2013;28(5):525-530.

13. Monickaraj F, Aravind S, Gokulakrishnan K, et al. Accelerated aging as evidenced by increased telomere shortening and mitochondrial DNA depletion in patients with type 2 diabetes. Mol Cell Biochem. 2012;365(12):343-50.

14. Matthews DR, Hosker JP, Rudenski AS, et al. Homeostasis model assessment: insulin resistance and beta cell function from plasma FBS and insulin concentrations in man. Diabetologia.1985;28(7):412-9.

15. Katz A, Nambi SS, Mather K, et al. Quantitative insulin sensitivity check index: a simple, accurate method for assessing insulin sensitivity in humans. J Clin Endocrinol Metab. 2000;85(7):2402-2410.

16. Tice RR, Agurell E, Anderson D, et al. Single cell gel/comet assay: guidelines for in vitro and in vivo genetictoxicology testing, Environ Mol Mutagen. 2000;35(3):206-221.

17. Al-Aubaidy HA, Jelinek HF. Oxidative DNA damage: antioxidan response in postprandial hyperglycaemia in type 2 diabetes mellitus. $J$ Diabetes Vasc Dis. 2011;11:87-91.

18. Matough FA, Budin SB, Hamid ZA, et al. The role of oxidative stress and antioxidants in diabetes complications. Sultan Oaboos Univ J. 2012;12(1):5e-e18

19. Pan HZ, Zhang L, Guo MY, et al. The oxidative stress status in diabetes mellitus and diabetes nephropathy. Acta Diabetol. 2010;47(Suppl 1):7176

20. Odum EP, Ejilemele AA, Wakwe VC. Antioxidant status of type 2 diabetic patients in Port Harcourt, Nigeria. Niger J Clin Pract. 2012;15(1):55-58.

21. Shi YC, Pan TM. Red mold, diabetes, and oxidative stress: A review. Appl Microbiol Biotechnol. 2012;94(1):47-55.

22. Lima V, Sampaio F, Bezerra D. Parameters of glycemic control and their relationship with zinc concentrations in blood and with superoxide dismutase enzyme activity in type 2 diabetes patients. Arq Bras Endocrinol Metab. 2011;55(9):701-707.

23. Kumawat M, Pahwa M, Gahlaut V, et al. Status of antioxidant enzymes and lipid peroxidation in Type 2 diabetes mellitus with micro vascular complications. The Open Endocrinology Journal. 2009;3:12-15.

24. Kavitha G, Ramani G, Dhass P, et al. Oxidative stress, interleukin (IL-6) and atherogenic index of plasma in diabetic nephropathy. International Journal of Applied Biology and Pharmaceutical Technology. 2011;2(2):211-216.

25. Moussa SA. Oxidative stress in diabetes mellitus. Romanian J Biophys 2008;18(3):225-36.

26. Kumawat M, Pahwa MB, Gahlaut VS, et al. Status of antioxidant enzymes and lipid peroxidation in type 2 diabetes mellitus with micro vascular complications. Open Endocrinol J. 2009;3:12-5.

27. Kumawat M, Singh I, Singh N, et al. Lipid peroxidation and lipid profile in type 2 diabetes mellitus. Webmed Central Biochem 2012;3:WMC003147.

28. Bhutia Y, Ghosh A, Sherpa ML, et al. Serum malondialdehyde level: Surrogate stress marker in the Sikkimese diabetics. J Nat Sci Biol Med. 2011;2(1):107-12.

29. Nour Eldin EE, Almarzouki A, Assiri AM, et al. Oxidized low density lipoprotein and total antioxidant capacity in type-2 diabetic and impaired glucose tolerance Saudi men. Dia-betol Metab Syndr. 2014;6(1):94.

30. Volpe CM. The production of nitric oxide. IL-6, and TNF-alpha in palmitate- stimulated PBMNCs is enhanced through hyperglycemia in diabetes. Oxid Med Cell Longev. 2014;2014:479587.

31. Kolluru GK, Bir SC, Kevil CG. Endothelial dysfunction and diabetes: Effects on angiogenesis, vascular remodeling, and wound healing. Int $J$ Vasc Med. 2012;2012:1-30.

32. Niedowicz DM, Daleke DL. The role of oxidative stress in diabetes complications. Cell Biochem Biophys. 2005;43(2):289-330.

33. Pavlović D, Kocić R, Kocić G, et al. Effect of four-week metformin treatment on plasma and erythrocyte antioxidative defense enzymes in newly diagnosed obese patients with type 2 diabetes. Diabet Obes Metab. 2000;2(4):251-256 
34. Dinçer Y, Alademir Z, Ilkova H, et al. Susceptibility of glutathione and glutathione-related antioxidant activity to hydrogen peroxide in patients with type 2 diabetes: effect of glycemic control. Clin Biochem. 2002;35(4):297-301

35. Bhatia S, Shukla R, Madhu SV, et al. Antioxidant status, lipid peroxidation and nitric oxide end products in patients of type 2 diabetes mellitus with nephropathy. Clin Biochem. 2003;36(7):557-562.

36. Moussa SA. Oxidative stress in diabetes mellitus. Romanian J Biophys. 2008;18(3):225-36

37. Likidlilid A, Patchanans N, Peerapatdit T, et al. Lipid peroxidation and antioxidant enzyme activities in erythrocytes of type 2 diabetes patients. $J$ Med Assoc Thai. 2010;93(6):682-693.
38. Matough FA, Budin SB, Hamid ZA, et al. The role of oxidative stress and antioxidants in diabetes complications. Sultan Qaboos Univ J. 2012;12(1):5-18

39. Tatsch E, Bochi GV, Piva SJ, et al. (2012) Association between DNA strand breakage and oxidative, inflammatory and endothelial biomarkers in type 2 diabetes. Mutat Res. 2012;732(1-2):16-20.

40. Mauricio MD, Aldasoro M, Ortega J, et al. (2013) Endothelial dysfunction in morbid obesity. Curr Pharm Des. 2013;19(32):5718-5729. 